\title{
Influence of Storage Conditions on Physico-Chemical and Biochemical of Two Tangerine Cultivars
}

\author{
Worawaran Roongruangsri ${ }^{1}$, Nithiya Rattanapanone ${ }^{1}$, Noppol Leksawasdi ${ }^{2} \&$ Danai Boonyakiat ${ }^{1}$ \\ ${ }^{1}$ Postharvest Technology Research Institute, Chiang Mai University, Chiang Mai, Thailand \\ ${ }^{2}$ Faculty of Agro-Industry, Chiang Mai University, Chiang Mai, Thailand \\ Correspondence: Worawaran Roongruangsri, Postharvest Technology Research Institute, Chiang Mai University, \\ Chiang Mai, Thailand. E-mail: worawaran@rmutl.ac.th
}

Received: October 12, 2012 Accepted: November 9, 2012 Online Published: January 15, 2013

doi:10.5539/jas.v5n2p70 URL: http://dx.doi.org/10.5539/jas.v5n2p70

\begin{abstract}
The influences of on-tree, off-tree and cold storage on physico-chemical and biochemical were studied and quite similar between thetwo tangerine cultivars, 'Sai Num Phueng' and 'See Thong'. In both cultivars, the percentage of weight loss increased and the moisture content of the peel (\%) decreased at higher temperature and longer duration. Low temperature storage at $5^{\circ} \mathrm{C}$ reduced the losses of fruit weight and moisture content of the peel and preserved the external quality better than $25^{\circ} \mathrm{C}$ storage. During on-tree and off-tree storage at 25 and $5^{\circ} \mathrm{C}$, peel chlorophyll content decreased and peel carotenoid content increased. Titratable acidity (TA), citric acid, isocitric acid and vitamin $\mathrm{C}$ contents decreased and juice $\mathrm{pH}$ increased. Malic acid content stayed relatively constant. Total soluble solids (TSS), TSS/TA ratio and sucrose content continually increased. Glucose and fructose contents slightly increased. The peel chlorophyll content, TA and citric acid content decreased faster during storage on-tree than at $25^{\circ} \mathrm{C}$. The peel carotenoid, TSS and sucrose contents increased greater during storage on-tree than at $25^{\circ} \mathrm{C}$. The delayed declining of peel chlorophyll, TA, and citric acid contents and the slow increases of the peel carotenoid, TSS and sucrose contents were observed at $5^{\circ} \mathrm{C}$ storage in comparison to $25^{\circ} \mathrm{C}$. The activities of mitochondrial citrate synthase, cytosolic aconitase and cytosolic NADP-isocitrate dehydrogenase (NADP-IDH) were lower and decreased faster during storage at $25^{\circ} \mathrm{C}$ in comparison to storage on-tree. The activities of these enzymes, which related to citric acid metabolism, were slowed down which resulted in delaying the decrease of citric acid content during storage at $5^{\circ} \mathrm{C}$ in comparison to $25^{\circ} \mathrm{C}$.
\end{abstract}

Keywords: tangerine fruit, storage, physico-chemical changes, biochemical changes

\section{Introduction}

Tangerine (Citrus reticulata Blanco) is a non-climacteric subtropical fruit and widely grown in many countries such as China, Spain, India, Japan, Italy and Turkey (Ladaniya, 2008). Tangerine is also the main citrus fruits grown in Thailand and the production area is in the northern part (Office of Comercial Affairs Chiang mai, 2008). Tangerine fruit is a good source of vitamin C (Ahmad et al., 2006).

Physico-chemical changes during storage of some citrus fruit have been reported. The increase in TSS was generally observed for various citrus cultivars while organic acids (mainly citric acid) gradually declined during postharvest storage (Baldwin, 1993). Higher storage temperature of citrus fruit resulted in rapid water loss and caused an increase in the TSS and a rapidly drops of TA and citric acid content (Ladaniya, 2008). Vitamin C decreased during storage under ambient and refrigerated conditions and even more rapid at higher temperatures (Rapisarda et al., 2001). Enzyme activities (e.g., pyruvate decarboxylase and alcohol dehydrogenase) have been determined during storage (Seehanam et al., 2010).

The final citric acid concentration in ripened fruit was the balance of organic acid biosynthesis, degradation and vacuolar storage (Muller et al., 1996). The enzymes potentially involved in citric acid metabolism including citrate synthase (EC 4.1.3.7) (Sadka et al., 2001), aconitase (EC 4.2.1.3) (Sadka et al., 2000a) and NADP-IDH (EC 1.1.1.42) (Sadka et al., 2000b). Although tangerine cultivars have been successfully grown and consumed in Thailand, but no publication were found on their physico-chemical and biochemicalcharacteristics during development and storage. Therefore, the objective of this study was to evaluate 
the effect of on-tree and off-tree storage on physico-chemical and biochemical changes of the two tangerine cultivars, 'Sai Num Phueng' and 'See Thong'.

\section{Materials and Methods}

\subsection{Fruit Materials}

After full bloom period, the young tangerine fruit (about $0.3 \mathrm{~cm}$ equatorial diameter) cv. 'Sai Num Phueng' and 'See Thong' were tagged on each fruit of the seven trees which grown at the Chiang Mai Thanathon orchard, Thailand. The tagged 150-170 fruits per cultivars were collected at the age of 37 weeks after full bloom (WAF) and counted as day 0 for either on-tree and off-tree storage at 25 and $5^{\circ} \mathrm{C}$. For on-tree storage, the other tagged fruit were left on-tree and then harvested every 5 days for 30 days. For off-tree storage, the fruit were washed with tap water and air dried. Fruit were placed in plastic baskets and stored at $25^{\circ} \mathrm{C}, 85 \pm 2 \%$ relative humidity (RH) and $5^{\circ} \mathrm{C}, 58 \pm 2 \% \mathrm{RH}$ in the incubators. For each sampling, 9 tagged fruits of each cultivar were harvested and divided into three replicates with 3 fruits per replication. Each fruit was carefully dissected into pulp and peel. The pooled pulp and peel of each replication were immediately frozen in liquid $\mathrm{N} 2$ and stored at $-70^{\circ} \mathrm{C}$ until analysis. For sample preparation, the frozen peel of each replication was ground to a fine powder with a household blender. The frozen pulp of each replication was thawed and juice extracted using the same blender and filtered through 3 layers of muslin cloth to remove the pulp.

\subsection{Determination of Weight Loss and Moisture Content of the Peel}

Weight loss was determined with samples of 9 fruit per cultivar. Fruit from each cultivar were weighed on a 5 days interval during 30 days storage period at $25^{\circ} \mathrm{C}$ and 7 days interval during 56 days storage at $5^{\circ} \mathrm{C}$. The weight losses were expressed as the percentages of their initial weight. The moisture content of the peel was determined by drying at $105^{\circ} \mathrm{C}$ until constant (AOAC, 2005).

\subsection{Sensory Evaluation of Fruit Visual Appearance}

Tangerine fruit were rated for visual quality, wilting and shriveling, using a scale of 1 to 5 in which $5=$ excellent, $4=$ good, $3=$ unacceptable, $2=$ poor and $1=$ very poor. Fruit appearance was rated "unacceptable" when the score was less than or equal 3.

\subsection{Measurement of Peel and Juice Color}

Peel and juice colors of tangerine fruit were quantified objectively (lightness: L, chroma and hue angle values) using a colorimeter (ColorQuest XE, Hunterlab, Virginia) (McGuire, 1992). Nine fruits were randomly selected from each cultivar to measure the peel color. Tangerine juice color was analyzed through an optical glass cuvettes of $12.5 \mathrm{~mm}$ path length backed with black cardboard reflectors of approximately $5 \%$ reflection in triplicate of each replication and averaged.

\subsection{Determination of Carotenoid}

Carotenoid was extracted with hexane: acetone: ethanolin the ratio of 50:25:25 v/v from the peel powder (Wang et al., 2007) and the juice (Lee et al., 2001). All operations were conducted under subdued light to minimize oxidation of the carotenoids. All glassware was wrapped in aluminum foil to minimize exposure to light. All extracts were made and measured in triplicate for each replication and averaged. The total carotenoid content in peel and juice was measured at the absorbance of $450 \mathrm{~nm}$ with the extinction coefficient of 2,592 and expressed as $\beta$-carotene equivalents in $\mu \mathrm{g} \mathrm{g}^{-1}$ Fresh Weight (FW) for the peel and in $\mu \mathrm{g} \mathrm{g}^{-1}$ juice for the juice.

\subsection{Chlorophyll Extraction and Quantification}

The chlorophyll a, b and total chlorophyll from the peel powder were extracted with $80 \%(\mathrm{v} / \mathrm{v})$ acetoneand determined by measuring the absorbance at 663 and $645 \mathrm{~nm}$ with implementation of the Arnon's equations and expressed the calculated values in $\mu \mathrm{g} \mathrm{g}^{-1} \mathrm{FW}$. The analysis was in triplicate for each replication and averaged (Rodrigo et al., 2003).

\subsection{Measurement of TA Juice $\mathrm{pH}$ and TSS}

The TA was determined by titration of $5 \mathrm{ml}$ juice with $0.1 \mathrm{M} \mathrm{NaOH}$ until $\mathrm{pH} 8.1$ and expressed as percentage of citric acid per $100 \mathrm{~g}$ juice) (AOAC, 2005). The $\mathrm{pH}$ value of juice was measured through a digital $\mathrm{pH}$ meter(Consort C831, Belgium) (AOAC, 2005). The TSS was determined using digital refractometer (ATAGO PR-101, Japan) at room temperature (AOAC, 2005). The TA, TSS and TSS/TA ratio were determined in triplicate for each replication and averaged. 


\subsection{Assessment of Organic Acids}

The $25 \mathrm{~g}$ juice was homogenized with $25 \mathrm{ml}$ of $4.5 \%(\mathrm{w} / \mathrm{v})$ metaphosphoric acid solution and filtered through a $0.45 \mu \mathrm{m}$ nylon membrane filter. The filtrate was analyzed by high-performance liquid chromatography (HPLC) (HP series 1100, Agilent, Waldbrom, Germany). Organic acids were separated by an ultra aqueous C18 column $(4.6 \times 250 \mathrm{~mm}, 5 \mu \mathrm{m}$, Restek, Germany). Detection was carried out by a visible wavelength detector (VWD) at 210 $\mathrm{nm}$. Temperature of the column oven was set at $35^{\circ} \mathrm{C}$. Mobile phase was $50 \mathrm{mMortho-phosphoric} \mathrm{acid}(\mathrm{v} / \mathrm{v})$ at a flow rate $0.5 \mathrm{ml} / \mathrm{min}$ for $30 \mathrm{~min}$. A $20 \mu \mathrm{l}$ of each sample were put into an injection loop with an automatic system (Aarabi et al., 2008). Authentic standards of citric acid, malic acid, isocitric acid and ascorbic acid or vitamin C were prepared in $0.05 \%(\mathrm{w} / \mathrm{v})$ metaphosphoric acid. HPLC samples were run in triplicate for each replication and averaged.

\subsection{Determination of Sugars}

A $10 \mathrm{~g}$ of juice sample was diluted (1/5 dilution) with deionized water and adjusted the final volume to $50 \mathrm{ml}$ in a volumetric flask. The diluted supernatant was then filtered through $0.45 \mu \mathrm{m}$ pore size nylon membrane filter. The filtrate was analyzed by HPLC with separation by a Zorbax carbohydrate column $(4.6 \times 150 \mathrm{~mm}, 5 \mu \mathrm{m}$ dp, Agilent Technologies, Waldbrown, Germany). Refractive index detector (RID) was connected in series and temperature of the column oven was set at $30^{\circ} \mathrm{C}$. Mobile phase was 25:75 of deionized water: acetonenitrile (Merck, Darmstadt, Germany) at a $1.4 \mathrm{ml} /$ minute flow rate and 10-12 minutes stop time. The $5 \mu 1$ of the sample was directly injected into the HPLC (Cabálková \& Chmelik, 2002). Sucrose, glucose, and fructose were used as standards. HPLC samples were run in triplicate for each replication and averaged.

\subsection{Fractionation of Juice Sac Cells and Enzyme Assays}

Juice vesicles of tangerine fruit were fractionated into cytosolic or soluble fraction and a crude fraction enriched with mitochondria as described by Sadka et al. (2000a) with slight modifications. Citrate synthase activity was determined by using Ellman's reagent [5,5'-dithiobis-(2-nitrobenzoic acid), DTNB]. The assay mixture was 1,500 $\mu 1$ and total volume composed of $0.2 \mathrm{mM}$ acetyl-CoA, $0.5 \mathrm{mM}$ oxaloacetate and $0.1 \mathrm{mM}$ DTNB in $50 \mathrm{mM}$ Tris- $\mathrm{HCl}$ ( $\mathrm{pH}$ 7.8). The reaction was started by adding $20-50 \mu \mathrm{l}$ of the extracted enzyme. The reaction product thionitrobenzoic acid (TNB) was the absorbing substance with intense absorption at $412 \mathrm{~nm}, 30^{\circ} \mathrm{C}$ (Kuznetsov et al., 2006). Aconitase activity was determined using $1,500 \mu \mathrm{l}$, mixture composed of $40 \mathrm{mMTris}-\mathrm{HCl}(\mathrm{pH} 7.5), 100$ $\mathrm{mM} \mathrm{NaCl}$ and $0.2 \mathrm{mM}$ cis-aconitic acid. The reaction was started by adding 50-100 $\mu \mathrm{l}$ of the extracted enzyme, and the declining of cis-aconitic acid was followed by measuring the absorbance at $240 \mathrm{~nm}, 25^{\circ} \mathrm{C}$ (Hirai \& Ueno, 1977). NADP-IDH activity was performed in $1,500 \mu \mathrm{l}$ reaction mixture composed of $25 \mathrm{mM}$ Tris- $\mathrm{HCl}(\mathrm{pH} 7.5)$, $0.5 \mathrm{mM} D L$-isocitric acid, $1 \mathrm{mM} \beta$-NADP and $5 \mathrm{mM} \mathrm{MgSO}_{4}$. The reaction was started by adding $20-50 \mu 1$ of the extracted enzyme. The recorded increase in production of NADPH at absorbance $340 \mathrm{~nm}, 37^{\circ} \mathrm{C}$ was carried out (Kubo et al., 2002). All three enzymes activities were determined in duplicate for each replication and averaged. The protein content of the fractionated extracts were quantified according to the dye-binding assay at the absorbance of $595 \mathrm{~nm}$ (Bradford, 1976) in triplicate for each replication and averaged.

\subsection{Statistical Analysis}

All data were analyzed by analysis of variance (ANOVA) using SPSS version 14 and the differences between samping periods and cultivars were analyzed by a Least Significant Difference (LSD) comparison. The level of significant difference was indicated with the following: $P<0.05$ for all comparisons.

\section{Results and Discussion}

\subsection{Changes in Weight Loss, Moisture Content of the Peel and Visual Appearance Score}

The percentage of weight loss significantly increased $(\mathrm{p} \leq 0.05)$ and no significant difference $(P>0.05)$ was detected between 'Sai Num Phueng' and 'See Thong' cultivars throughout storage period at 25 and $5^{\circ} \mathrm{C}$. The weight loss was higher during storage at $25^{\circ} \mathrm{C}$ in comparison to $5^{\circ} \mathrm{C}$. Low temperature storage at $5^{\circ} \mathrm{C}$ effectively delayed the weight loss $(0.23 \%$ per day in both cultivars $)$ in comparison to $25^{\circ} \mathrm{C}(0.60 \%$ per day in both cultivars $)$ (data not shown).

Moisture content of the peel (\%) for 'Sai Num Phueng' was not significant different $(P>0.05)$ from 'See Thong'. This content of both cultivars remained almost constant for 10 days, then slightly decreasedduring on-tree storage but gradually decreased throughout off-tree storage at 25 and $5^{\circ} \mathrm{C}$. The decrease in moisture content of the peel during storage at $5^{\circ} \mathrm{C}$ was lower than at $25^{\circ} \mathrm{C}$. Moisture content of the peel decreased about $2-3 \%$ during storage on-tree for 15 days, $11-12 \%$ at $25^{\circ} \mathrm{C}$ for 15 days, and about $6-7 \%$ after storage at $5^{\circ} \mathrm{C}$ for 14 days (data not shown). 
Fruit appearance was rated "unacceptable" when the score was equal or below 3 from 5 . The result indicated that there were a continuously decrease in the visual appearance score from the early storage until the end storage time during on-tree and off-tree storage at 25 and $5^{\circ} \mathrm{C}$. There was no significant difference $(P>0.05)$ in the visual appearance score between the two tangerine cultivars throughout storage periods. On day 15 of on-tree storage, both cultivars reached the unacceptable score and appeared the rind color around the peel without shrivel or wrinkle. While during storage at 25 and $5^{\circ} \mathrm{C}$, both cultivars reached the unacceptable score on day 10 and day 28 , respectively and appeared shrivel or wrinkle but not found the rind color (data not shown).

The losses of fruit weight and moisture content of the peel were mainly caused by fruit transpiration in which water moved out and resulted in wilted rind and a shriveled appearance (Wills et al., 2007). In orange and mandarin, even $5-6 \%$ water loss could result in some changes in appearance and firmness of the fruit that could be detrimental to its marketability (Ladaniya, 2008). Storage tangerine fruit at low temperature $\left(5^{\circ} \mathrm{C}\right)$ could reduce the weight loss and the peel moisture content loss. Similar results were obtained with two blood orange varieties. The data showed that the increase of weight loss was greater at $22^{\circ} \mathrm{C}$ storage than $8^{\circ} \mathrm{C}$ (Rapisarda et al., 2001). Low temperature storage for fresh orange and mandarin was required to operate within the range of $1-5^{\circ} \mathrm{C}$ (Ladaniya, 2008). Usually, the fruit weight loss and the water loss in peel were more rapidly during storage under low-humidity condition (Ladaniya, 2008). However, the results found that the losses of fruit weight and moisture content of the peel during storage at $5^{\circ} \mathrm{C}, 58 \pm 2 \% \mathrm{RH}$ were lower than that of at $25^{\circ} \mathrm{C}, 85 \pm 2 \% \mathrm{RH}$ in both tangerine cultivars. This trend was similar to tangerine fruit with various coatings, which the weight loss was relatively slow at $5^{\circ} \mathrm{C}, 64 \% \mathrm{RH}$ in comparison to at $25^{\circ} \mathrm{C}, 87 \% \mathrm{RH}$ (Roongruangsri et al., 2009). These could be suggested that the temperature storage had a greater influence than the relative humidity in the control of weight loss and moisture content of the peel.

\subsection{Changes in Peeltristimulus Color and Pigments}

Peel color changed from yellow-orange to orange during on-tree and off-tree storage at 25 and $5^{\circ} \mathrm{C}$. Peel $\mathrm{L}$, chroma and hue angle values did not significantly differ $(P>0.05)$ between both cultivars. Peel $\mathrm{L}$ value of both cultivars remained almost constant, chroma value slightly increased and hue angle value slightly decreased during on-tree storage for 20 days. Thereafter, peel $\mathrm{L}$ and chroma values decreased and hue angle value remained almost constant. During storage at 25 and $5^{\circ} \mathrm{C}$, peel $\mathrm{L}$ and hue angle values slightly decreased and chroma value slowly increased. After on-tree storage for 15 days, peel L, chroma and hue angle values were 66.40, 70.32 and 64.85 for 'Sai Num Phueng' and 66.06, 71.15 and 63.92 for 'See Thong', respectively. During off-tree storage at $25^{\circ} \mathrm{C}$ for 15 days, these values were 63.38, 67.32 and 67.63 for 'Sai Num Phueng' and 64.44, 66.25 and 69.97 for 'See Thong', respectively. However, during storage off-tree at $5^{\circ} \mathrm{C}$ for 14 days, these values were slightly different with 63.15 , 64.66 and 70.46 for 'Sai Num Phueng' and 65.66, 66.93 and 70.54 for 'See Thong', respectively (data not shown).

Peel chlorophyll $\mathrm{a}$ and $\mathrm{b}$ and total chlorophyll contents were not significantly different $(P>0.05)$ between both cultivars.Peel total carotenoid content of 'Sai Num Phueng' cultivar was significantly lower $(P \leq 0.05)$ than 'See Thong' cultivar. During on-tree storage, peel chlorophyll a, b and total chlorophyll contents of both cultivars continually decreased until day 20 and then remained almost constant at low levels. Peel total carotenoid content continually increased until day 20 and then decreased. Throughout storage at 25 and $5^{\circ} \mathrm{C}$, peel chlorophyll a, b and total chlorophyll contents slowly decreased and peel total carotenoid content slightly increased. The decrease in peel total chlorophyll content and the increase in peel total carotenoid content were faster during storage on-tree than at $25^{\circ} \mathrm{C}$ (Figure 1). Peel total chlorophyll content of 'Sai Num Phueng' and 'See Thong' cultivars bleached up to 69 and $63 \%$ during on-tree storage for 15 days, 46 and $40 \%$ after storage at $25^{\circ} \mathrm{C}$ for 15 days, and 26 and $31 \%$ after storage at $5^{\circ} \mathrm{C}$ for 14 days, respectively. Peel total carotenoid content increased about 24 and $29 \%$ after on-tree storage for 15 days, about 18 and $16 \%$ at $25^{\circ} \mathrm{C}$ for 15 days, and about 12 and $14 \%$ after storage at $5^{\circ} \mathrm{C}$ for 14 days, respectively.

The loss of green color was the obvious changes of the fruit, which was due to the degradation of chlorophyll and the accumulation in carotenoid pigments during storage (Wills et al., 2007). Total chlorophyll content declined and total carotenoid content increased in parallel with the decrease in the hue angle value showing the peel of both cultivars turned from yellow-orange to orange throughout on-tree and off-tree storage at 25 and $5^{\circ} \mathrm{C}$. The storage temperature influenced on the color changes of citrus fruit through biochemical processes and hormone levels in the fruit (Goldschmidt, 1988). Carotenoid content of Satsuma mandarin in the peel rapidly increased under storage condition at $20^{\circ} \mathrm{C}$. This was in contrary to storage at $5^{\circ} \mathrm{C}$, carotenoid content in the peel slowly increased (Matsumoto et al., 2009). The optimal temperature for carotenoid accumulation in the peel was in the range of $15-25^{\circ} \mathrm{C}$ (Rodrigo \& Zacarias, 2007). 

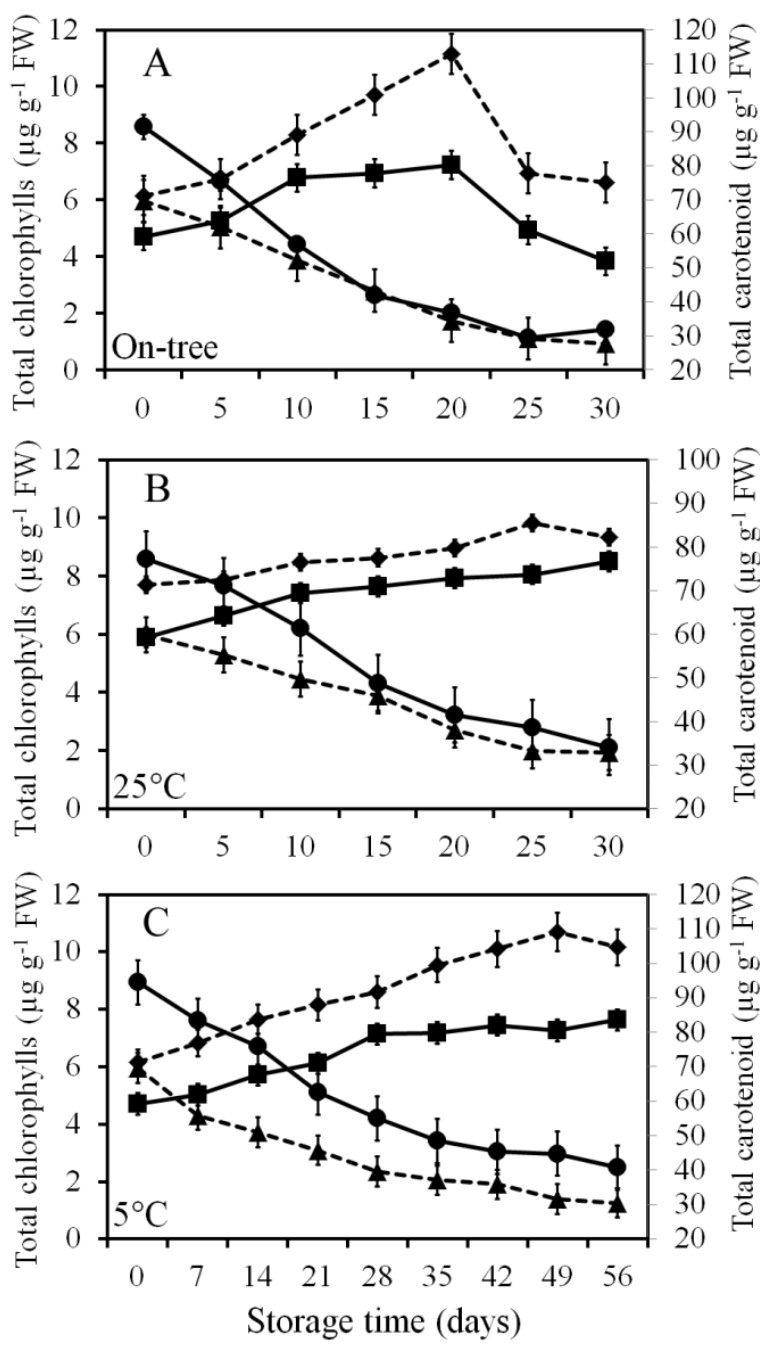

Figure 1. Changes in peel total chlorophyll and peel total carotenoid contents during on-tree (A) and off-tree storage at $25^{\circ} \mathrm{C}(\mathrm{B})$ and $5^{\circ} \mathrm{C}(\mathrm{C})$ of two tangerine fruit, 'Sai Num Phueng' and 'See Thong'

- peel total chlorophyll of 'Sai Num Phueng', $\boldsymbol{\Delta}$ peel total chlorophyll of 'See Thong', $\boldsymbol{\square}$ peel total carotenoid of 'Sai Num Phueng' and peel total carotenoid of 'See Thong'

\subsection{Changes in Juice Tristimulus Color and Pigments}

Juice $\mathrm{L}$, chroma and hue angle values for both cultivars were not significantly different $(P>0.05)$. During on-tree storage, juice $L$ value of both cultivars remained almost constant, juice chroma value increased and juice hue angle value decreased until day 20 . Thereafter, juice $\mathrm{L}$ and chroma values slightly decreased and juice hue angle value remained stable. During storage at 25 and $5^{\circ} \mathrm{C}$, juice $\mathrm{L}$ value remained almost constant while juice chroma value slightly decreased and juice hue angle value slightly increased. After on-tree storage for 15 days, juice L, chroma and hue angle values were 42.70, 40.19 and 76.00 for 'Sai Num Phueng' and 41.41, 40.12 and 77.48 for 'See Thong', respectively. During off-tree storage at $25^{\circ} \mathrm{C}$ for 15 days, these values were $44.54,36.32$ and 78.22 for 'Sai Num Phueng' and 43.08, 36.17 and 79.82 for 'See Thong', respectively. After off-tree storage at $5^{\circ} \mathrm{C}$ for 14 days, these values were 43.34, 38.18 and 78.10 for 'Sai Num Phueng' and 42.43, 37.52 and 78.36 for 'See Thong', respectively (data not shown).

Juice total carotenoid content did not significantly differ $(P>0.05)$ among 'Sai Num Phueng' and 'See Thong' cultivars. This content continually increased until day 20 , and then decreased during on-tree storage in both cultivars. It increased about 16 and $15 \%$ after storage on-tree for 15 days, respectively. However, this content continually decreased throughout storage at $25^{\circ} \mathrm{C}$ while slightly decreased during storage at $5^{\circ} \mathrm{C}$. It decreased about 14 and $16 \%$ during storage at $25^{\circ} \mathrm{C}$ for 15 days, and about 4 and $3 \%$ after storage at $5^{\circ} \mathrm{C}$ for 14 days, respectively (Figure 2). 
Carotenoid content in juice sacs of orange was accumulated during fruit maturation (Lee \& Castle, 2001) and slightly declined during storage (Rodrigo \& Zacarias, 2007). This content were maintained during storage at $5^{\circ} \mathrm{C}$ but gradually decreased during storage at $25^{\circ} \mathrm{C}$ in both tangerine cultivars. The similar results was reported in with 'Valencia late' orange juice (Meléndez-Martínez et al., 2007) and Satsuma mandarin (Matsumoto et al., 2009).
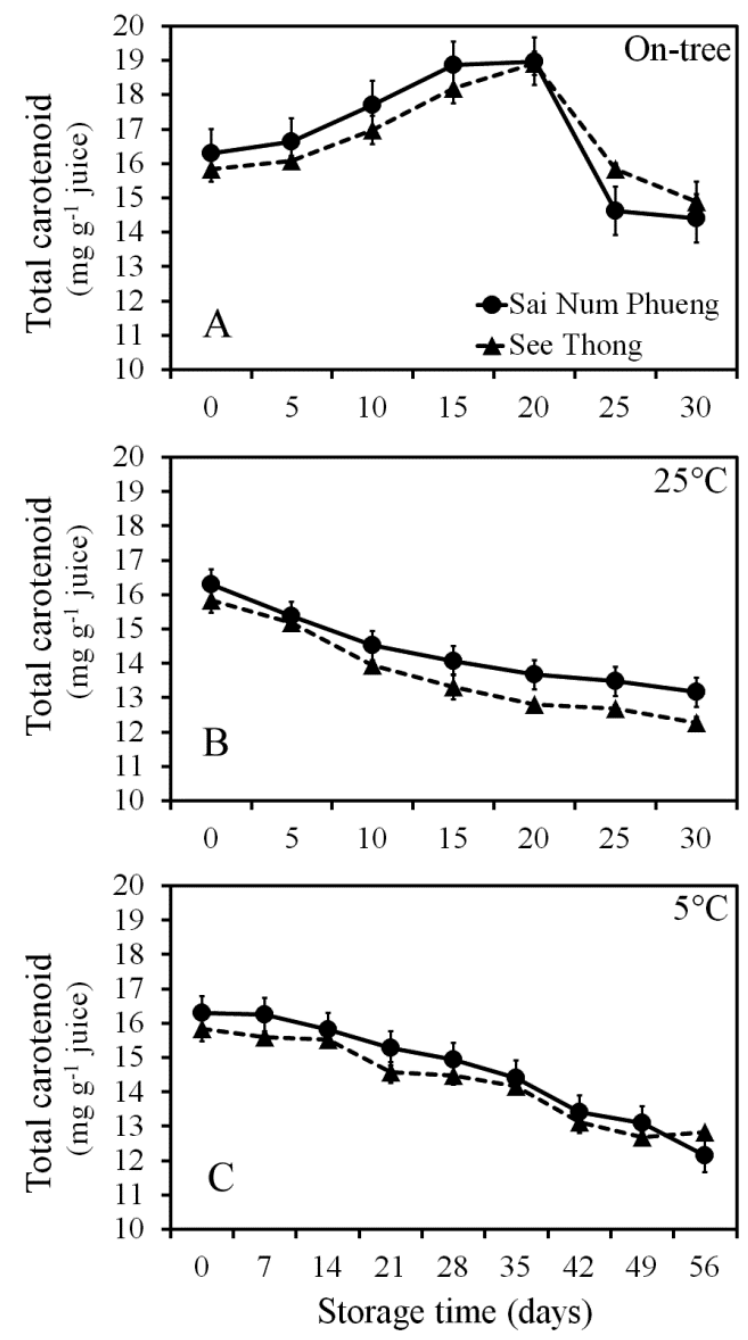

Figure 2. Changes in juice total carotenoid content during on-tree (A) and off-tree storage at $25^{\circ} \mathrm{C}(\mathrm{B})$ and $5^{\circ} \mathrm{C}(\mathrm{C})$ of two tangerine cultivars, 'Sai Num Phueng' $(\bullet)$ and 'See Thong'

\subsection{Changes in TA, Juice pH and Organic Acids Contents}

TA of 'Sai Num Phueng' was significantly higher $(P \leq 0.05)$ than 'See Thong' and continually decreased in both cultivars during on-tree and off-tree storage at 25 and $5^{\circ} \mathrm{C}$ (Figure 3). The initially TA of 'Sai Num Phueng' and 'See Thong' cultivars was 0.86 and $0.69 \%$ (of citric acid per $100 \mathrm{~g}$ juice), respectively. The decrease in TA was faster during storage on-tree than at $25^{\circ} \mathrm{C}$. The decrease in TA was slower during storage at $5^{\circ} \mathrm{C}$ than at $25^{\circ} \mathrm{C}$. TA decreased to 0.63 and $0.53 \%$ during storage on-tree for 15 days, in comparison to 0.72 and $0.62 \%$ at $25^{\circ} \mathrm{C}$ for 15 days, and decreased to 0.79 and $0.66 \%$ after storage at $5^{\circ} \mathrm{C}$ for 14 days, respectively.

The initial juice $\mathrm{pH}$ of both cultivars was 3.51 and 3.76 which 'Sai Num Phueng' had a significant lower juice $\mathrm{pH}$ than 'See Thong'. Juice $\mathrm{pH}$ increased to 3.92 and 4.12 after storage on-tree for 15 days, to 3.77 and 3.90 at $25^{\circ} \mathrm{C}$ for 15 days, and to 3.75 and 3.90 during storage at $5^{\circ} \mathrm{C}$ for 14 days, respectively (data not shown).

Citric acid content was significantly higher $(P \leq 0.05)$ in 'Sai Num Phueng' in comparison with 'See Thong' and continually decreased throughout on-tree and off-tree storage at 25 and $5^{\circ} \mathrm{C}$ (Figure 3 ). The initial citric acid content of both cultivars was 9.12 and $6.52 \mathrm{mg} \mathrm{g}^{-1}$ juice, respectively. The decrease in citric acid content was faster 
during storage on-tree than at $25^{\circ} \mathrm{C}$ as the storage period progressed. The decrease in this content was slower during storage at $5^{\circ} \mathrm{C}$ than at $25^{\circ} \mathrm{C}$. Citric acid content decreased to 5.01 and $4.97 \mathrm{mg} \mathrm{g}^{-1}$ juice during storage on-tree for 15 days, to 6.96 and $5.27 \mathrm{mg} \mathrm{g}^{-1}$ juice at $25^{\circ} \mathrm{C}$ for 15 days and to 7.28 and $5.67 \mathrm{mg} \mathrm{g}^{-1}$ juice after storage at $5^{\circ} \mathrm{C}$ for 14 days, respectively.
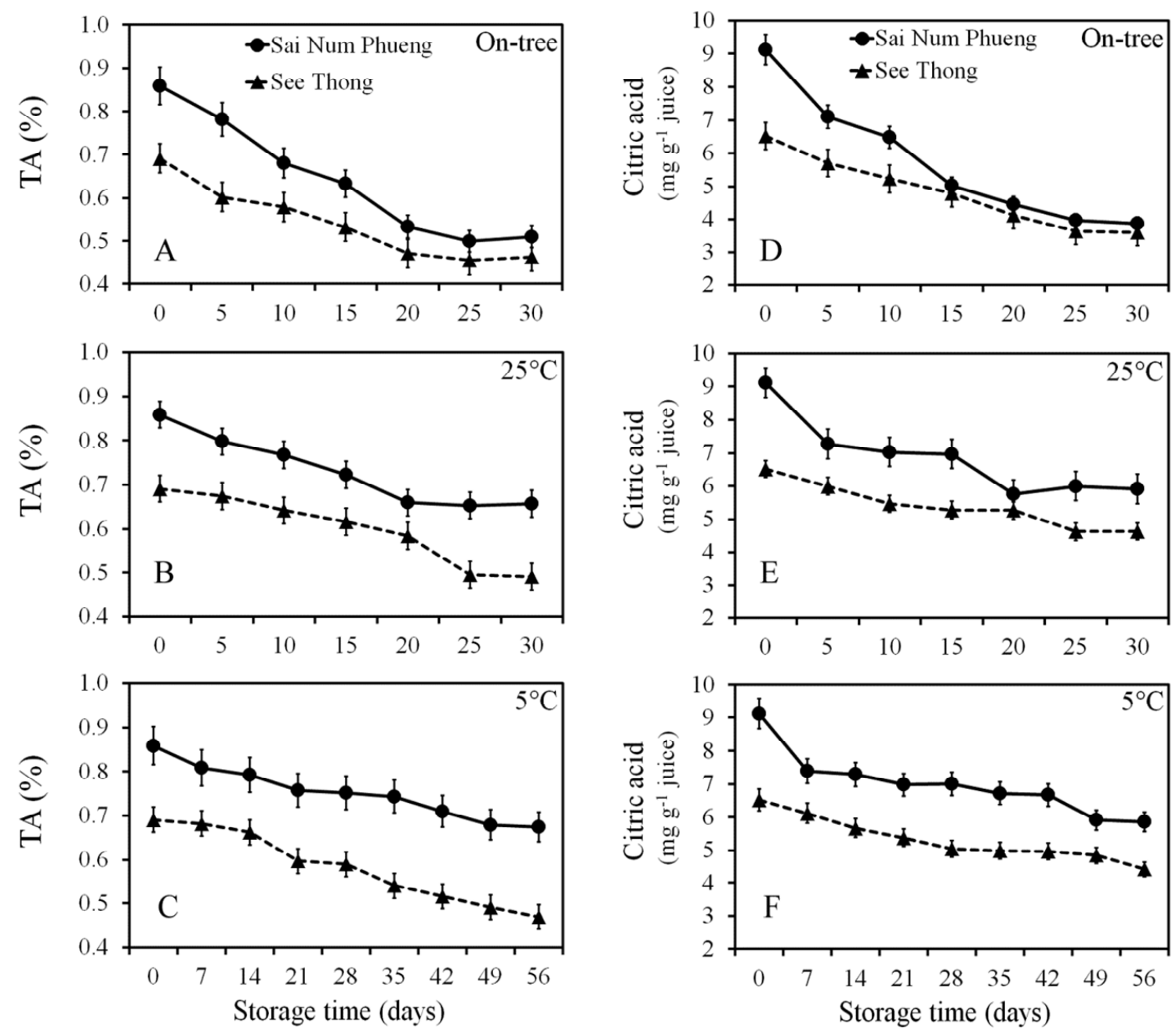

Figure 3. Changes in TA (left) and citric acid content (right) during on-tree (A and D) and off-tree storage at $25^{\circ} \mathrm{C}$ $(\mathrm{B}$ and $\mathrm{E})$ and $5^{\circ} \mathrm{C}(\mathrm{C}$ and $\mathrm{F})$ of two tangerine cultivars, 'Sai Num Phueng' $(\bullet)$ and 'See Thong' $(\boldsymbol{\Delta})$

The isocitric acid content of 'Sai Num Phueng' was significantly lower $(P \leq 0.05)$ than 'See Thong' and slightly decreased from 0.32 to $0.18 \mathrm{~g} \mathrm{mg} \mathrm{g}^{-1}$ juice during on-tree and off-tree storage at 25 and $5^{\circ} \mathrm{C}$. Malic acid content not significantly differ $(P>0.05)$ among both cultivars and remained relatively constant throughout on-tree and off-tree storage with $1.52-1.78 \mathrm{~g} \mathrm{mg} \mathrm{g}^{-1}$ juice (data not shown).

Vitamin $\mathrm{C}$ content of both tangerine cultivars slightly decreased during on-tree storage and continually decreased during storage at 25 and $5^{\circ} \mathrm{C}$. Sai Num Phueng' had significantly higher $(P \leq 0.05)$ in vitamin $\mathrm{C}$ content than that of 'See Thong' (Figure 4). The initial vitamin $\mathrm{C}$ content of both cultivars was 0.34 and $0.26 \mathrm{mg} \mathrm{g}^{-1}$ juice, respectively. This content of both cultivars during storage at $25^{\circ} \mathrm{C}$ decreased faster than storage on-tree or at $5^{\circ} \mathrm{C}$. Vitamin $\mathrm{C}$ content of 'Sai Num Phueng' and 'See Thong' cultivars decreased about 15 and 16\% during storage on-tree for 15 days, about 33 and $31 \%$ at $25^{\circ} \mathrm{C}$ for 15 days, and about 20 and $24 \%$ after storage at $5^{\circ} \mathrm{C}$ for 14 days, respectively.

Citric acid content had been reported to decrease during storage (Grierson \& Ben-Yehoshua, 1986) and also declined during cold storage in almost citrus fruit such as mandarin, orange and grapefruit (Ladaniya, 2008). The decline in citric acid content during storage of citrus fruit might be due to the utilization of organic acids for energy production (Purvis, 1983a). It might be due to the conversion of organic acids to sugar through gluconeogenesis 
(Echeverria \& Burns, 1989). It was also possible that acids were used for alcoholic fermentation in harvested citrus (Echeverria \& Burns, 1989).
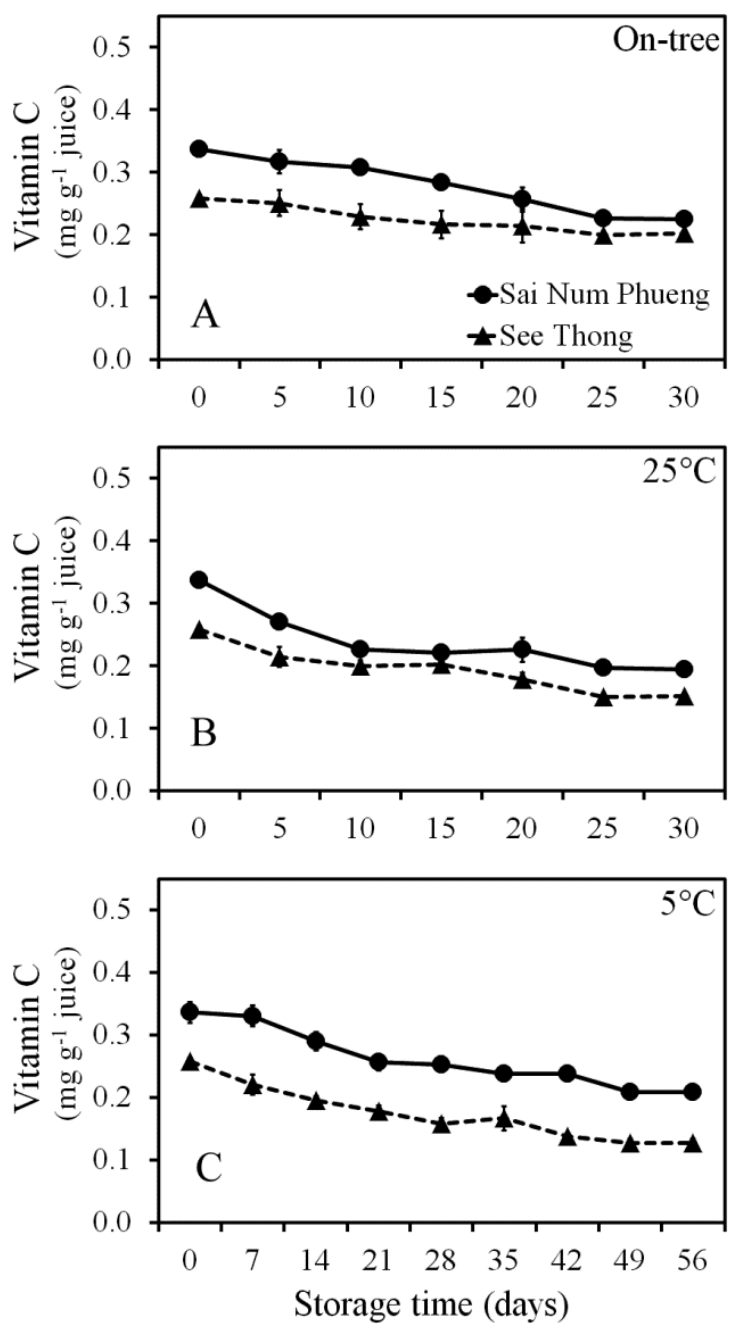

Figure 4. Changes in vitamin $\mathrm{C}$ content during on-tree (A) and off-tree storage at $25^{\circ} \mathrm{C}(\mathrm{B})$ and $5^{\circ} \mathrm{C}(\mathrm{C})$ of two tangerine cultivars, 'Sai Num Phueng' $(\bullet)$ and 'See Thong' $(\boldsymbol{\Delta})$.

The results showed that the decreases in TA and citric acid content were faster during storage on-tree than at $25^{\circ} \mathrm{C}$. This might be because of citrus fruit did not undergo rapid chemical or physical changes after removal from the tree (Ting \& Attaway, 1971). Moreover, during on-tree, citrus fruit required more organic acids (citric and malic acids) to create energy for carrying out metabolic reactions in transportation of metabolites, maintenance of cellular organization as well as membrane permeability, and to synthesis of new molecules in comparison with the detached fruitb (Ladaniya, 2008).

Higher storage temperature resulted in rapid water loss and caused the increase in TSS and the rapidly drop of TA and citric acid content (Chundawat et al., 1978). The results indicated the delayed decreasing in TA and citric acid content of both tangerine cultivars at $5^{\circ} \mathrm{C}$ in comparison with $25^{\circ} \mathrm{C}$. This trend was similar to 'Hayashi' Satsuma in which the loss in TA was relatively slow at minimum level of $5^{\circ} \mathrm{C}$ than at $15^{\circ} \mathrm{C}$ for up to 2 months (Izumi et al., 1990). If the temperature was kept at a higher level, the acidity tended to decline at a faster rate in various sweet orange cultivars (Chattopadhyay et al., 1992).

The loss of vitamin C about 10-20\% in usual handling and marketing practices of fresh fruit were common (Wills et al., 2007). The longer duration of storage resulted in the higher vitamin C loss of citrus fruit (Ting \& Attaway, 1971). Various reports had shown that vitamin $\mathrm{C}$ decreased under ambient and refrigerated conditions during storage of citrus fruit such as blood orange, sweet orange and mandarin (Rapisarda et al., 2001). The vitamin C loss was more rapid at 
higher temperatures storage (Wills et al., 1984) and also agreed with the report for 'Hayashi' Satsuma that the vitamin $\mathrm{C}$ content decreased slower at $5^{\circ} \mathrm{C}$ than at $15^{\circ} \mathrm{C}$ (Izumi et al., 1990).

\subsection{Changes in TSS, TSS/TA Ratio and Sugars Contents}

TSS (\%) of 'Sai Num Phueng' was significantly higher $(\mathrm{p} \leq 0.05)$ than 'See Thong' throughout on-tree and off-tree storage at 25 and $5^{\circ} \mathrm{C}$ (Figure 5) and the initial TSS were 11.38 and $11.10 \%$ respectively. During on-tree storage, TSS of both cultivars increased until day 20 and then slightly decreased. TSS continually increased during storage at 25 and $5^{\circ} \mathrm{C}$. TSS increased to 13.19 and $12.83 \%$ after storage on-tree for 15 days, to $12.50 \%$ and $12.08 \%$ at $25^{\circ} \mathrm{C}$ for 15 days, and to 12.23 and $11.90 \%$ during storage at $5^{\circ} \mathrm{C}$ for 14 days, respectively.
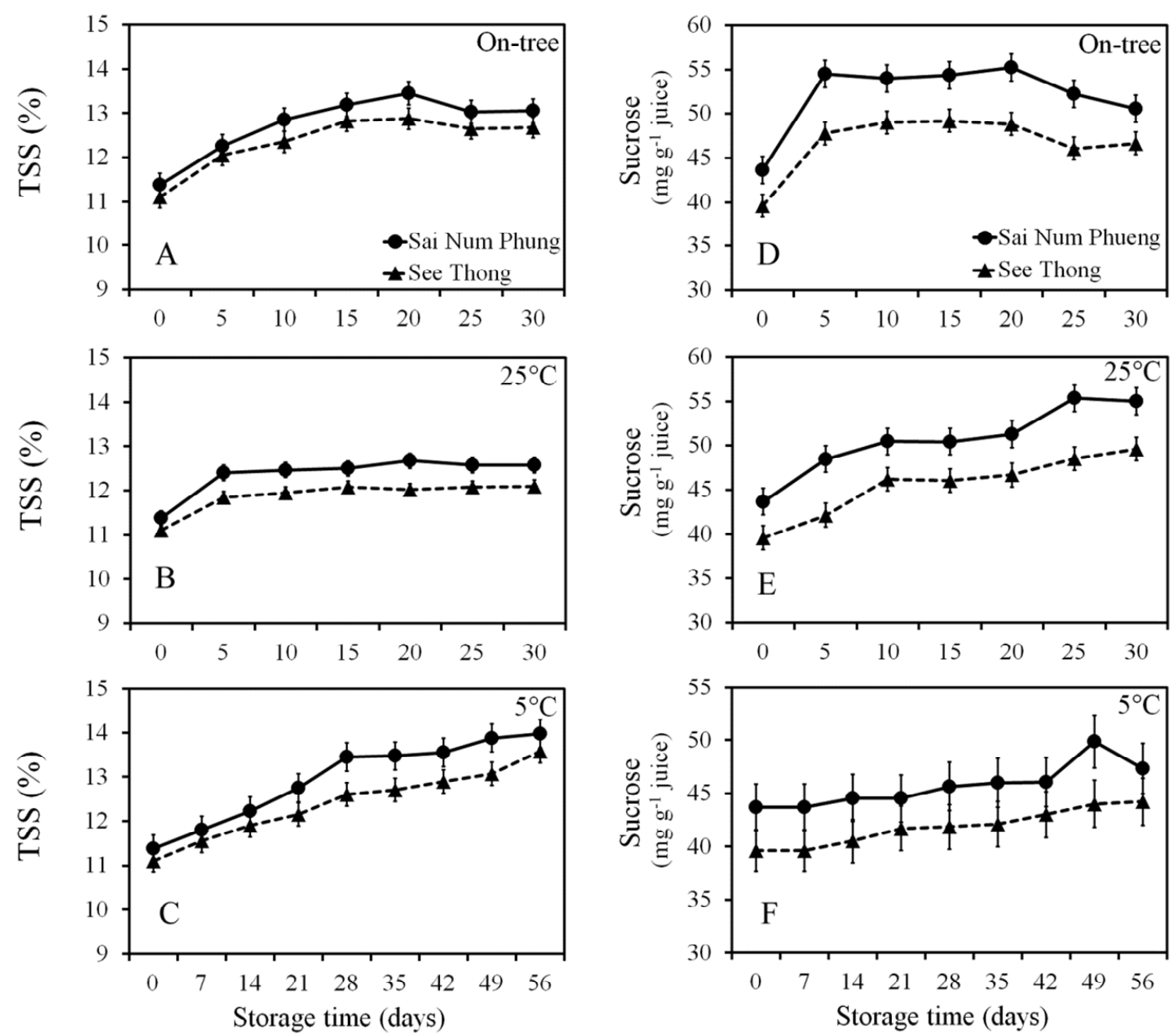

Figure 5. Changes in TSS (left) and sucrose content (right) during on-tree (A and D) and off-tree storage at $25^{\circ} \mathrm{C}(\mathrm{B}$ and $\mathrm{E})$ and $5^{\circ} \mathrm{C}(\mathrm{C}$ and $\mathrm{F})$ of two tangerine cultivars, 'Sai Num Phueng' $(\bullet)$ and 'See Thong'

TSS/TA ratio was increased and significantly lower $(\mathrm{p} \leq 0.05)$ in 'Sai Num Phueng' than 'See Thong during on-tree and off-tree storage at 25 and $5^{\circ} \mathrm{C}$. The initial TSS/TA ratio of 'Sai Num Phueng' and 'See Thong' cultivars was 13.26 and 16.07, respectively. TSS/TA ratio during storage on-tree was significantly higher than $25^{\circ} \mathrm{C}$ throughout storage period. TSS/TA ratio increased to 20.85 and 24.11 during storage on-tree for 15 days, to 18.04 and 20.53 at $25^{\circ} \mathrm{C}$ for 15 days, and to 15.53 and 17.99 after storage at $5^{\circ} \mathrm{C}$ for 14 days, respectively (data not shown).

Sucrose content of 'Sai Num Phueng' was significantly higher $(\mathrm{p} \leq 0.05)$ than that of 'See Thong'. The initial sucrose content was 43.69 and $39.61 \mathrm{mg} \mathrm{g}^{-1}$ juice, respectively. During on-tree storage, sucrose content increased until day 20 and then slightly decreased. This content was slightly higher during storage on-tree than at $25^{\circ} \mathrm{C}$. The increase in sucrose content was slower during storage at $5^{\circ} \mathrm{C}$ than that of $25^{\circ} \mathrm{C}$ throughout storage period (Figure 5). 
The sucrose content was 54.33 and $49.21 \mathrm{mg} \mathrm{g}^{-1}$ juice during storage on-tree for 15 days, 50.45 and $46.06 \mathrm{mg} \mathrm{g}^{-1}$ juice at $25^{\circ} \mathrm{C}$ for 15 days, as well as 44.55 and $40.51 \mathrm{mg} \mathrm{g}^{-1}$ juice after storage at $5^{\circ} \mathrm{C}$ for 14 days, respectively (data not shown).

Glucose and fructose contents of 'Sai Num Phueng' were significantly higher $(\mathrm{p} \leq 0.05)$ than 'See Thong' and increased very slightly throughout storage on-tree and off-tree at 25 and $5^{\circ} \mathrm{C}$. In 'Sai Num Phueng' and 'See Thong' cultivars, glucose content increased in the range $19.24-24.56 \mathrm{mg} \mathrm{g}^{-1}$ juice and 16.22-20.46 mg $\mathrm{g}^{-1}$ juice, respectively. Fructose content increased in the range $24.55-27.60 \mathrm{mg} \mathrm{g}^{-1}$ juice and 18.49-23.04 $\mathrm{mg} \mathrm{g}^{-1}$ juice, respectively (data not shown).

The increase in TSS and the decrease in TA during storage for both tangerine cultivars agreed with several varieties of citrus fruit (Purvis, 1983b) such as 'Tacle' and 'Clara' mandarin (Rapisarda et al., 2008b), 'Ougan' and 'Hongju' mandarin (Ye et al., 2000). In 'Hamlin' orange and 'Robinson' tangerine, the increase in TSS was accompanied by a parallel increase in sucrose and a concomitant decline in acid content during 9 weeks of storage at $15^{\circ} \mathrm{C}$ (Echeverria \& Ismail, 1987). The previous study found that the increase in TSS was not only due to water loss and the consequential increase in solute concentrations (Purvis, 1983b). The possible reasons causing TSS increase and TA decrease was due to the conversion of organic acids to sugars through gluconeogenesis (Echeverria \& Ismail, 1987). Moreover, the degradation of cellulose, hemicellulose and pectin from cell walls within fruit segments might release soluble components which could have a direct effect on TSS (Echeverria et al., 1988). It was found that solubilization of cell water constituents bygalactosidases and glucosidases presented in citrus fruit, might have contributed to increase in TSS levels (Echeverria, 1990).

The results showed that TSS and sucrose content were higher during storage on-tree than at $25^{\circ} \mathrm{C}$. It was possible that in the off-tree fruit, the additional soluble sugars (photoassimilate), which produced from the photosynthesis had already ceased (Echeverria \& Ismail., 1987). Conversion of organic acids to sugars through the gluconeogenic pathway was possible but only during the first weeks after harvest (Echeverria \& Ismail., 1987). This was compared to the on-tree fruit which still had the photosynthesis activity to continue sugar synthesis process (Kays \& Paull, 2004).

The decrease in acid contents and the increase in TSS resulted in the increase in TSS/TA ratio of both tangerine cultivars during on-tree and off-tree storage at 25 and $5^{\circ} \mathrm{C}$. The increase in TSS/TA ratio had influenced on the taste due to lower acidity and stronger sweetness (Iglesias \& Echeverria, 2009). During storage of orange, organic acids decreased faster than sugars so that the fruit was predicted to be slightly sweeter in holding (Samson, 1986). TSS/TA ratio increased by $10 \%$ along with a 20 -folds increase in ethanol (Echeverria \& Ismail, 1990).

\subsection{Changes in Citrate Synthase, Aconitase and NADP-IDH Activities}

Citrate synthase activity was detected only in mitochondrial fraction. Aconitase activity was detected in both mitochondrial and cytosolic fractions. NADP-isocitrate dehydrogenase (NADP-IDH) activity was detected in cytosolic fraction.

\subsubsection{Mitochondrial Citrate Synthase Activity}

Mitochondrial citrate synthase activity was not significantly different $(P>0.05)$ between 'Sai Num Phueng' and 'See Thong' cultivars throughout on-tree and off-tree storage at 25 and $5^{\circ} \mathrm{C}$ (Figure 6 ). The initial mitochondrial citrate synthase activity was 2.82 and 2.93 unit mg $^{-1}$ protein, respectively. Mitochondrial citrate synthase activity remained almost constant until day 10 and then slightly decreased during storage on-tree. However, this activity continuously decreased throughout storage at $25^{\circ} \mathrm{C}$ while sharply decreased on day 7 and then remained relatively constant at low level until the end of storage period at $5^{\circ} \mathrm{C}$. Mitochondrial citrate synthase activity was 2.59 and

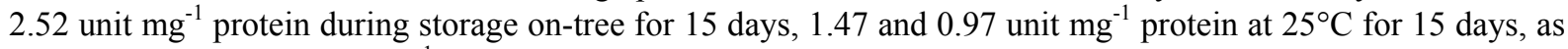
well as 0.62 and 0.67 unit $\mathrm{mg}^{-1}$ protein after storage at $5^{\circ} \mathrm{C}$ for 14 days, respectively. 

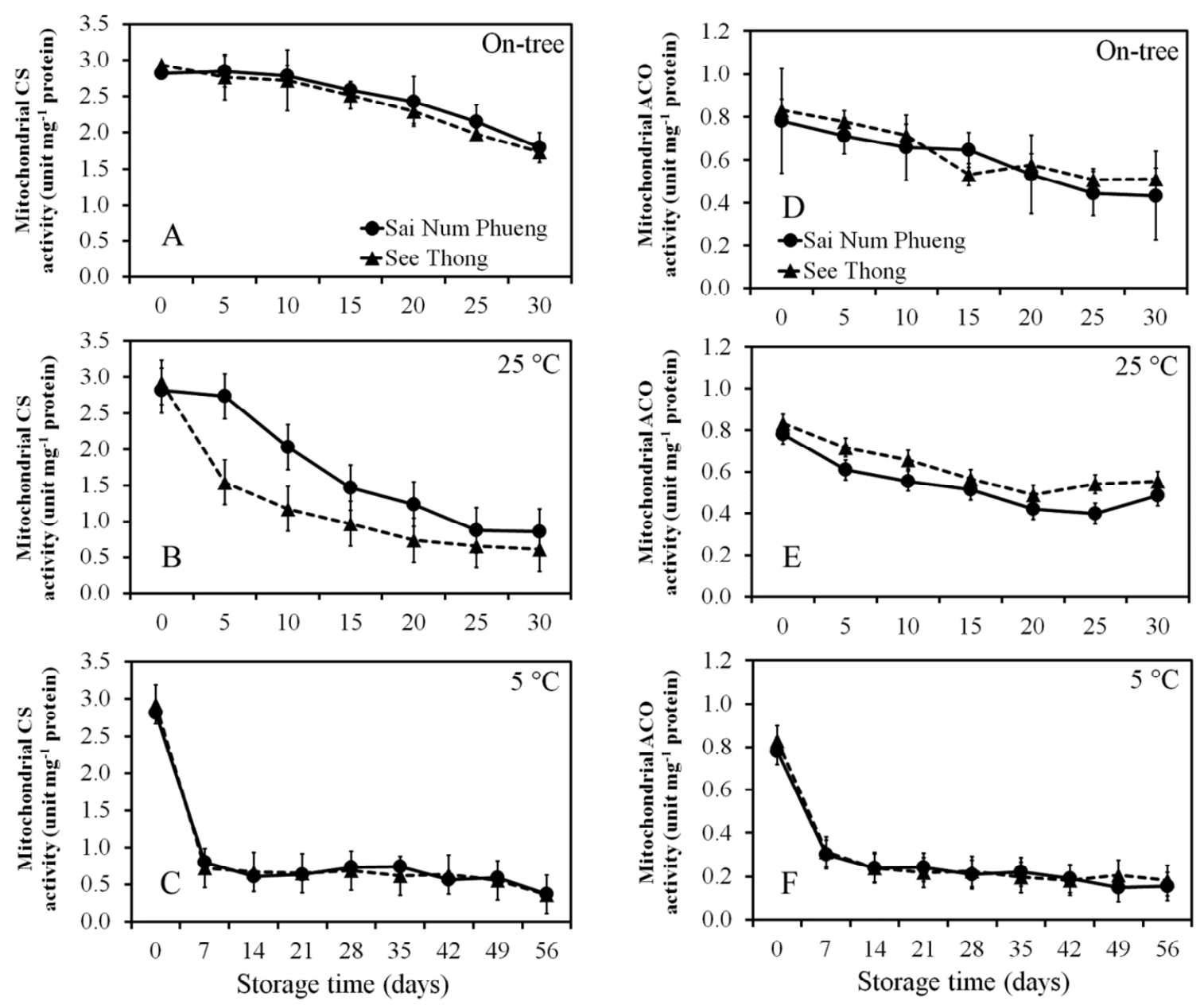

Figure 6. Changes in activities of citrate synthase (CS, left) and aconitase (ACO, right) in mitochondrial fraction during on-tree (A and $\mathrm{D})$ and off-tree storage at $25^{\circ} \mathrm{C}(\mathrm{B}$ and $\mathrm{E})$ and $5^{\circ} \mathrm{C}(\mathrm{C}$ and $\mathrm{F})$ of two tangerine cultivars, 'Sai Num Phueng' $(\bullet)$ and 'See Thong' $(\boldsymbol{\Lambda})$

\subsubsection{Mitochondrial Aconitase Activity}

Aconitase activity in the mitochondrial fraction was not significantly different $(P>0.05)$ between the two tangerine cultivars throughout on-tree and off-tree storage at 25 and $5^{\circ} \mathrm{C}$ (Figure 6). The initial mitochondrial aconitase activity of 'Sai Num Phueng' and 'See Thong' cultivars was 0.78 and 0.83 unit mg ${ }^{-1}$ protein, respectively. This activity slightly decreased during storage on-tree and off-tree at 25 and $5^{\circ} \mathrm{C}$. Mitochondrial aconitase activity was 0.65 and 0.53 unit mg $^{-1}$ protein during storage on-tree for 15 days, 0.51 and $0.57 \mathrm{mg} \mathrm{g}^{-1}$ juice at $25^{\circ} \mathrm{C}$ for 15

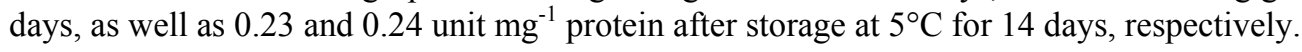

\subsubsection{Cytosolic Aconitase and NADP-IDH Activities}

Aconitase and NADP-IDH activities in the cytosolic fraction did not differ significantly $(P>0.05)$ between 'Sai Num Phueng' and 'See Thong' cultivars (Figure 7). The initial cytosolic aconitase activity was 3.21 and 3.43 unit $\mathrm{mg}^{-1}$ protein and cytosolic NADP-IDH activity was 0.24 and 0.25 unit mg $^{-1}$ protein, respectively. Cytosolic aconitase and NADP-IDH activities remained stable until day 10 and then significantly decreased during storage on-tree of both cultivars. These two enzyme activities gradually decreased throughout storage at $25^{\circ} \mathrm{C}$ but rapidly decreased on day 7 , and then remained almost constant at very low level throughout storage period at $5^{\circ} \mathrm{C}$. Aconitase activity was 2.28 and 2.27 unit mg $^{-1}$ protein during storage on-tree for 15 days, 1.85 and $1.63 \mathrm{unit} \mathrm{mg}^{-1}$ protein at $25^{\circ} \mathrm{C}$ for 15 days, as well as 0.39 and 0.42 unit mg $^{-1}$ protein after storage at $5^{\circ} \mathrm{C}$ for 14 days, respectively. NADP-IDH activity was 0.20 and 0.19 unit mg $^{-1}$ protein during storage on-tree for 15 days, 0.16 and $0.17 \mathrm{unit} \mathrm{mg}^{-1}$

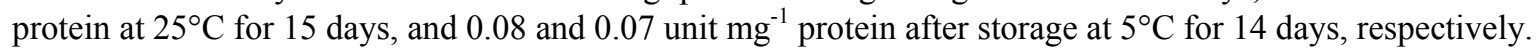



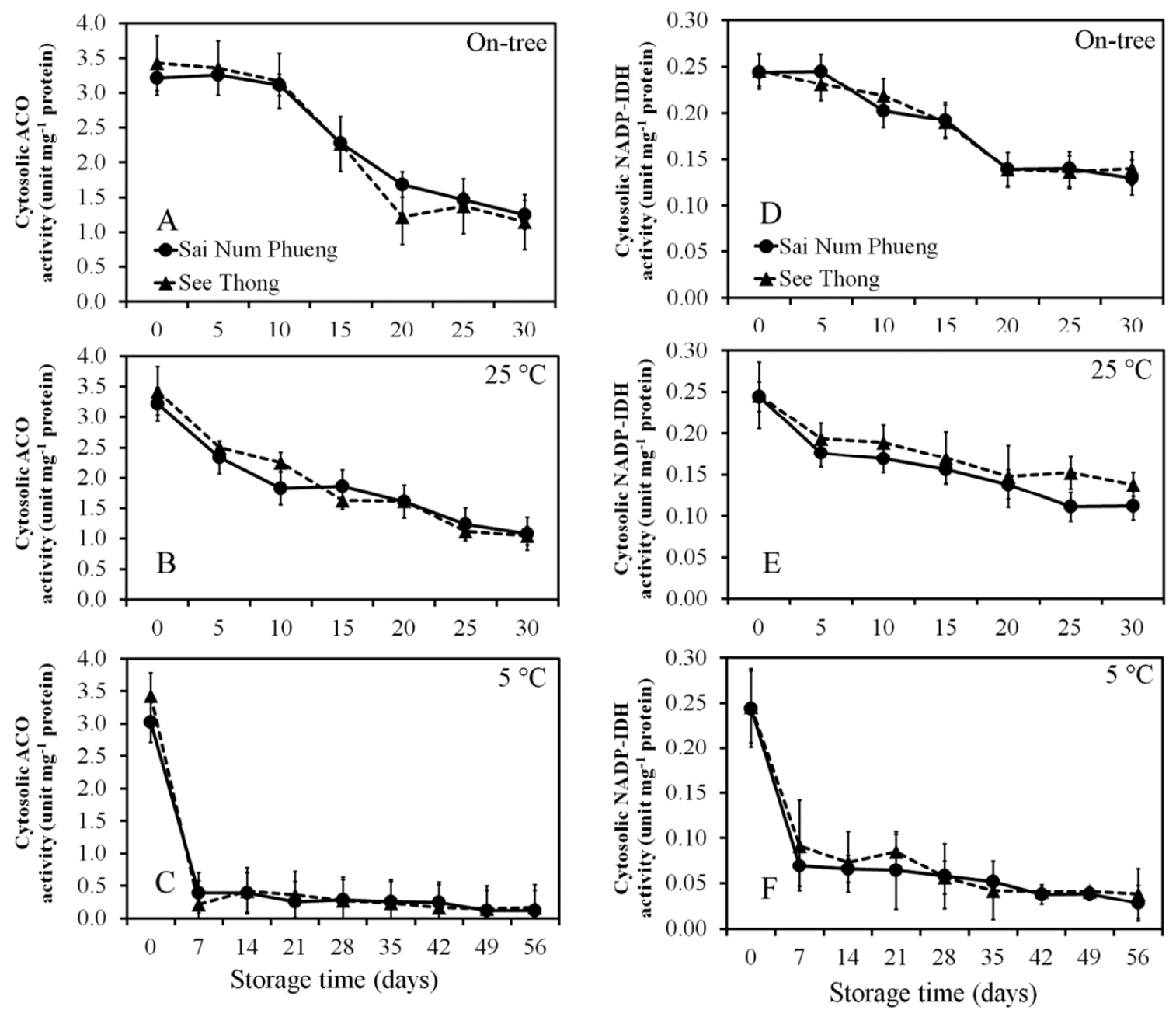

Figure 7. Changes in activities of aconitase (ACO, left) and NADP-IDH (right) in cytosolic fraction during on-tree (A and D) and off-tree storage at $25^{\circ} \mathrm{C}(\mathrm{B}$ and $\mathrm{E})$ and $5^{\circ} \mathrm{C}(\mathrm{C}$ and $\mathrm{F})$ of two tangerine cultivars, 'Sai Num Phueng'

$(\bullet)$ and 'See Thong' $(\boldsymbol{\Delta})$

The activities of mitochondrial citrate synthase, cytosolic aconitase and cytosolic NADP-IDH decreased faster during storage at $25^{\circ} \mathrm{C}$ in comparison to storage on-tree. These three enzyme activities were higher during storage at $25^{\circ} \mathrm{C}$ than at $5^{\circ} \mathrm{C}$ (Figures 6-7). The biochemical changes during storage of citrus fruit had been reported for pyruvate decarboxylase and alcohol dehydrogenase activities of coated tangerine fruit. It was indicated that these enzyme activities were lower during storage at $5^{\circ} \mathrm{C}$ than at ambient temperature (Seehanam et al., 2010). Moreover, the activities of polyphenoloxidase, peroxidase (Chauhan et al., 1980), polymethylesterase, polygalacturonase, and cellulose (Nagar, 1994) increased during ambient temperature storage, which indicated the senescence of citrus fruit (Davis \& Albrigo, 1994). During storage of tomato at $20^{\circ} \mathrm{C}$, alcohol dehydrogenase activity remained constant throughout the storage period. The activity of this enzyme decreased after storage for 6 days at $10^{\circ} \mathrm{C}$ which was lower than the fruit at $20^{\circ} \mathrm{C}$ storage (De Leon-Sanchez et al., 2009). The results showed that cytosolic aconitase and cytosolic NADP-IDH activities in both cultivars stored at $25^{\circ} \mathrm{C}$ showed greater decrease than the fruit left on-tree. This was in agreement with citric acid content of these fruit stored $25^{\circ} \mathrm{C}$ which showed the lower decrease in citric acid content than the fruit left on-tree.

\section{Conclusion}

The effects of on-tree, off-tree and cold storage on physico-chemical and biochemical changes were quite similar in 'Sai Num Phueng' and 'See Thong' cultivars. Low temperature storage at $5^{\circ} \mathrm{C}$ reduced the losses of fruit weight and moisture content of the peel and preserved the external quality better than $25^{\circ} \mathrm{C}$ storage. Both tangerine 
cultivars could store for almost 10 days at $25^{\circ} \mathrm{C}$ and 28 days at $5^{\circ} \mathrm{C}$, and could leave on the tree for 15 days without the loss in visual appearance. The peel chlorophyll content, TA and citric acid content decreased faster during storage on-tree than at $25^{\circ} \mathrm{C}$. The peel carotenoid, TSS and sucrose contents increased greater during storage on-tree than at $25^{\circ} \mathrm{C}$. The delayed declining of peel chlorophyll, TA, and citric acid contents and the slow increases of the peel carotenoid, TSS and sucrose contents were observed at $5^{\circ} \mathrm{C}$ storage in comparison to $25^{\circ} \mathrm{C}$. Low temperature storage could preserve carotenoid and vitamin $\mathrm{C}$ contents in juice better than $25^{\circ} \mathrm{C}$ storage. The activities of enzymes in relation to citric acid metabolism were slowed down which resulted in delaying the decrease of TA and citric acid content during storage at $5^{\circ} \mathrm{C}$ in comparison to $25^{\circ} \mathrm{C}$.

\section{Acknowledgments}

We thank the Office of the Higher Education Commission, Thailand, for supporting the grant fund under the program Strategic Scholarships for Frontier Research Network for the Ph.D. Program Thai Doctoral degree for this research. We also thank the Postharvest Technology Research Institute, Chiang Mai University, Thailand for their support. All tangerine fruit were supplied from Chiang Mai Thanathon Co., Ltd, Thailand.

\section{References}

Aarabi, A., Barzegar, M., \& Azizi, M. H. (2008). Effect of cultivar and cold storage of pomergranate (Punica granatum L.) juices on organic acid composition. Asean Food Journal, 15(1), 45-55.

Ahmad, J., Polson, M., Mackie, K., Quiroga, W., \& Patil, B. (2006). Citrus limonoids and flavanoids: Enhancement of Phase II detoxification enzymes and their potential in chemoprevention. In B. S. Patil, N. D. Turner, E. D. Miller, \& J. S. Brodbelt (Eds.), Potential health benefits of citrus (pp. 130-143). Washington DC: American Chemical Society.

AOAC. (2005). Official methods of analysis of AOAC International (18th ed.). Maryland, MD: Association of Official Analytical Chemists.

Baldwin, E. A. (1993). Citrus fruit. In G. B. Seymour, J. E. Taylor \& G. A. Tucker (Eds.), Biochemistry of Fruit Ripening (pp. 107-149). Cambridge, England: Great Britain at the University Press.

Bradford, M. M. (1976). A rapid and sensitive method for the quantitation of microgram quantities of protein utilizing the principle of protein-dye binding. Analytical Biochemistry, 72, 248-254.

Cabálková, J., \& Chmelik, J. (2002). Determination of sample carbohydrates in citrus juices by using capillary electrophoresis with indirect detection and high performance liquid chromatography. Chemistry Listy, Symposia, 96, 150-152.

Chattopadhyay, N., Hore, J. K., \& Sen, S. K. (1992). Extension of storage life of sweet orange (C. sinensis Osbeck) cv. Jaffa. Indian Journal of Plant Physiology, 35, 245-251.

Chauhan, K. S., Kainsa, R. L., \& Gupta, O. P. (1980). Enzymatic activity in citrus fruit as affected by various packages and length of storage. Haryana Journal of Horticultural Science, 9, 34-37.

Chundawat, B. S., Gupta, A. K., \& Singh, A. P. (1978). Storage behaviour of different grades of Kinnow fruit. Punjab Horticultural Journal, 18, 156-160.

Davis, F. S., \& Albrigo, L. G. (1994). Citrus. Oxford, UK: CAB International.

De Leon-Sanchez, F., Pelayo-Zaldivar, C., Rivera-Cabrera, F., Ponce-Valadez, M., Avila-Alejandre, X., \& Fernandez, F. J. (2009). Effect of refrigerated storage on aroma and alcohol dehydrogenase activity in tomato fruit. Postharvest Biology and Technology, 54, 93-100. http://dx.doi.org/10.1016/j.postharvbio.2009.07.003

Echeverria, E. (1990). Developmental transition from enzymatic to acid hydrolysis of sucrose in acid limes (Citrus aurantifolia). Plant Physioogyl., 92, 168-171. http://dx.doi.org/10.1104/pp.92.1.168

Echeverria, E., \& Burns, J. K. (1989). Vacuolar acid hydrolysis as a physiological mechanism for sucrose breakdown. Plant Physiology, 90, 530-533. http://dx.doi.org/10.1104/pp.90.2.530

Echeverria, E., \& Ismail, M. (1987). Changes in sugars and acids of citrus fruits during storage. Proc. Proceeding of Florida State Horticultural Society, 100, 50-52.

Echeverria, E., \& Ismail, M. (1990). Sugars unrelated to Brix changes in stored citrus fruits. HortScience, 25, 710-716.

Echeverria, E., \& Ismail., M. (1987). Changes in sugars and acids of citrus fruits during storage. Proceeding of Florida State Horticultural Society, 100, 50-52. 
Echeverria, E., Jacoqueline, K. B., \& Wicker, L. (1988). Effect of cell wall hydrolysis on Brix in citrus fruits. Proceeding of Florida State Horticultural Society, 101, 150-154.

Goldschmidt, E. E. (1988). Regulatory aspects of chloro-chromoplast interconversions in senescing citrus fruit peel. Israel Journal of Botany, 37, 123-130.

Grierson, W., \& Ben-Yehoshua, S. (1986). Storage of citrus fruits. In V. F. Wardowski, S. Nagy \& W. Grierson (Eds.), Fresh Citrus Fruits (pp. 479-507). Westport, Connecticut: Avi Publishing.

Hirai, M., \& Ueno, I. (1977). Development of citrus fruits: Fruit development and enzymatic changes in juice vesicle tissue. Plant and Cell Physiology, 18, 791-800.

Iglesias, I., \& Echeverria, G. (2009). Differential effect of cultivar and harvest date on nectarine colour, quality and consumer acceptance. Scientia Horticulturae, 120, 41-50.http://dx.doi.org/10.1016/j.scienta.2008.09.011

Izumi, H., Ito, T., \& Yoshida, Y. (1990). Changes in the fruit quality of Satsuma mandarin during storage after harvest from exterior and interior canopy of trees. Journal of the Japanese Society for Horticultural Science, $5,885-893$.

Kays, S. J., \& Paull, R. E. (2004). Postharvest Biology. Athen: Exon Press.

Kubo, T., Kihara, T., \& Hirabayashi, T. (2002). The effects of spraying lead arsenate on citrate accumulation and the related enzyme activities in the juice sacs of Citrusnatsudaidai. Journal of the Japanese Society for Horticultural Science, 71(3), 305-310.

Kuznetsov, A. V., Lassnig, B., \& Gnaiger, E. (2006). Laboratory protocol citrate synthase mitochondrial marker enzyme. Mitochondrial Physiology Network, 8(14), 1-8.

Ladaniya, M. S. (2008). Citrus Fruit Biology Technology and Evaluation. San Diego: Academic Press. http://dx.doi.org/10.1078\%2F1439-6092-00058

Lee, H. S., \& Castle, W. S. (2001). Seasonal changes of carotenoid pigments and color in Hamlin, Earlygold, and Budd blood orange juices. Journal of Agricultural and Food Chemistry, 49, 877-882.

Lee, H. S., Castle, W. S., \& Coates, G. A. (2001). High-performance liquid chromatography for the characterization of carotenoids in the new sweet orange (Earlygold) grown in Florida, USA. Journal of Chromatography, 913, 371-377.

Matsumoto, H., Ikoma, Y., Kato, M., Nakajima, N., \& Hasegawa, Y. (2009). Effect of postharvest temperature and ethylene on carotenoid accumulation in the flavedo and juice sacs of Satsuma mandarin (Citrus unshiu Marc.) fruit. Journal of Agricultural and Food Chemistry, 57(11), 4724-4732. http://dx.doi.org/10.1021/jf9005998

McGuire, R. G. (1992). Reporting of objective colour measurement. HortScience, 27(12), 1254-1255.

Meléndez-Martínez, A. J., Vicario, I. M., \& Heredia, F. J. (2007). Carotenoids, color, and ascorbic acid content of a novel frozen-marketed orange juice. Journal of Agricultural and Food Chemistry, 55(4), 1347-1355.http://dx.doi.org/10.1021/jf063025b

Muller, M. L., Irkens-Kiesecker, U., Rubinstein, B., \& Taiz, L. (1996). On the mechanism of hyperacidification in lemon. Journal of Biological Chemistry, 271, 1916-1924.

Nagar, P. K. (1994). Effect of some ripening retardants on fruit softning enzymes of Kinnow mandarin fruits. Indian Journal of Plant Physiology, 37, 122-124.

Office of Comercial Affairs Chiang Mai. (2008). Orange situation in Chiang Mai, crop year 2008/2009. Ministry of commerce Thailand, Chiang Mai, Thailand.

Purvis, A. C. (1983a). Moisture loss and juice quality from waxed and individually sealed-packaged Citrus fruit. Journal of the American Society for Horticultural Science, 96, 327-329.

Purvis, A. C. (1983b). Effect of film thickness and storage temperature on water loss and internal quality of sealed packed grape fruit. Journal of the American Society for Horticultural Science, 108, 562-566.

Rapisarda, P., Bellomo, S., Fabroni, S., \& Russo, G. (2008). Juice quality of two new mandarin-like hybrids (Citrus clementina Hort. ex Tan x Citrus sinensis L. Osbeck) containing anthocyanins. Journal of Agricultural and Food Chemistry, 56, 2074-2078. http://dx.doi.org/10.1021/jf020871n

Rapisarda, P., Bellomo, S. E., \& Intelisano, S. (2001). Storage temperature effects on blood orange fruit quality. Journal of Agricultural and Food Chemistry, 49, 3230-3235. http://dx.doi.org/10.1021/jf0100321 
Rodrigo, M., Marcos, J., Alferez, F., Mallent, M., \& Zacarias, L. (2003). Characterization of 'Pinalate', a novel Citrus sinensis mutant with a fruit-specific alteration that results in yellow pigmentation and decreased ABA content. Journal of Experimental Botany, 54, 727-738.http://dx.doi.org/10.1093/jxb/erg083

Rodrigo, M. J., \& Zacarias, L. (2007). Effect of postharvest ethylene treatment on carotenoid accumulation and the expression of carotenoid biosynthetic genes in the flavedo of orange (Citrus sinensis L. Osbeck) fruit. Postharvest Biology and Technology, 43(1), 14-22. http://dx.doi.org/10.1016/j.postharvbio.2006.07.008

Roongruangsri, W., Rattanapanone, N., \& Boonyakiat, D. (2009). Evaluation of a polyethylene-candelilla coating for tangerine fruit cv. 'Sai Nam Pung'. Chiangmai University Journal of Natural Sciences, 8(1), 67-76.

Sadka, A., Dahan, E., Cohen, L., \& Marsh, K. B. (2000a). Aconitase activity and expression during the

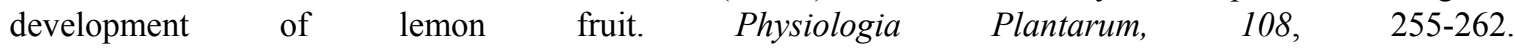
http://dx.doi.org/10.1034/j.1399-3054.2000.108003255.x

Sadka, A., Dahan, E., Etti, O., \& Cohen, L. (2000b). NADP ${ }^{+}$-isocitrate dehydrogenase gene expression and isozyme activity during citrus fruit development. Plant Science, 158, 173-181. http://dx.doi.org/10.1016/S0168-9452(00)00328-9,

Sadka, A., Dahan, E., Or, E., Roose, M. L., Marsh, K. B., \& Cohen, L. (2001). Comparative analysis of mitochondrial citrate synthase gene structure, transcript level and enzymatic activity in acidless and acid-containing Citrus varieties. Australian Journal of Plant Physiology, 28, 383-390. http://dx.doi.org/10.1071/PP00136

Samson, J. A. (1986). Citrus. In J. A. Samson (Ed.), Tropical Fruit (pp. 73-138). London: Longman.

Seehanam, P., Boonyakiat, D., \& Rattanapanone, N. (2010). Physiological and physicochemical responses of 'Sai Nam Phueng' tangerine to commercial coatings. Hort. Science, 45, 605-609.

Ting, S. V., \& Attaway, J. A. (1971). Citrus fruits. In A. C. Hulme (Ed.), The Biochemistry of Fruit and Their Products (pp. 107-169). London: Academic Press.

Wang, Y., Chuang, Y., \& Hsu, H. (2007). The flavonoid, carotenoid and pectin content in peels of citrus cultivated in Taiwan. Food Chemistry, 106, 277-284. http://dx.doi.org/10.1016/j.foodchem.2007.05.086

Wills, R., McGlasson, B., Graham, D., \& Joyce, D. (2007). Postharvest: An Introduction to the Physiology and Handling of Fruit, Vegetables and Ornamentals (2 edn). Sydney: University of New South Wales Press.

Wills, R., Wimalasiri, P., \& Greenfield, H. (1984). Dehydroascorbic acid levels in fresh fruit and vegetables in relation to total vitamin C activity. Journal of Agricultural and Food Chemistry, 32, 836-838. http://dx.doi.org/10.1021/jf00124a035

Ye, M. Z., Chen, Q. X., Xu, J. Z., Xu, X. Z., Zhao, M., \& Xia, K. S. (2000). Some physiological changes and storability of citrus fruits during storage. Plant Physiology Communications, 36, 125-127. 